\title{
Ownership Structure and Earnings Management: Evidence from Iran
}

\author{
Bashir Ghabdian ${ }^{1}$, Navid Attaran ${ }^{2} \&$ Omid Froutan ${ }^{1}$ \\ ${ }^{1}$ Department of Accounting, Neyshabur Branch, Islamic Azad University, Neyshabur, Iran \\ ${ }^{2}$ Faculty of Management, University of Tehran, Tehran, Iran \\ Correspondence: Omid Froutan, Department of Accounting, Neyshabur Branch, Islamic Azad University, \\ Neyshabur, Iran. E-mail: froutan_omid@yahoo.com
}

Received: May 11, 2012

doi:10.5539/ijbm.v7n15p88
Accepted: July 17, 2012

Published: August 1, 2012

\begin{abstract}
Family enterprises have been a major part of capital markets. By possessing most of their stock or being a member of the board, family members are considered the main decision makers in family businesses. Earnings on the other hand have always been a performance indicator which is under management control, most often managed or manipulated.This research seeks to identify and compare earnings management between family and non-family structured firms. After definingcriteria regarding family and non-family firms, 31 samples were selected as family based and they were grouped in relevant industries according to Tehran Stock Exchange categorization. Afterwards we randomly selected non-family firms from those industries with the same proportion. To test the research hypothesis, Jones adjusted model (Dechow et al, 1995) and multivariable regression model were used. The results indicate a meaningful relation between earnings management and ownership structure of firms where in average, non-family firms engagein earnings management more often than family ones.
\end{abstract}

Keywords: family firm, non-family firm, earnings management, accruals, discretionary accruals

\section{Introduction}

Family firms constitute around \%35 (175 firms) of 500 big American firms according to International Family Enterprise Research Academy (IFERA). Various criteria in different countries segregate family firms from non-family enterprises which lead to different surveys and most often contradictory results. Usually major blocks of family firms stock are owned by one or several family members where some of them are in fact in managerial positions serving the company. According to researchers had the level of stocks owned by managers' reaches certain levelthe outperforming incentive of managers is provoked. Although family matters come first in these enterprises and subsequently alignment of interest between major and minority shareholders is not certain at least in the long run. Ownership structure of firms can vary in different forms and wide range of individuals and organizations can be a part of it. Possessing most of the shares by one family or having a major influence on the board indicates the existence of a family firm. According to accounting theories (Hendriksen and Van Breda, 1993) the main reason of financial reporting is to produce useful information for decision makers. Managers worry about their own self interest not the owner's; hence they may manipulate or manage earnings to achieve the highest compensation. The main goal of this research is to study different aspects of family firmsespecially earnings management since the owners of the firm aresimultaneously the managers with no conflict of interest.

\section{Literature}

A study regarding the effect of founding family influence on firm value shows a meaningful discrepancy between the value of family and non-family enterprises where the first group has more value than the latest (Mishra et al, 2001). Andres (2008) investigated the profitability of 275 German listed companies and concludes that family enterprises are more profitable than publicly held firms.By scrutinizing S\&P 500 companies. Anderson and Reeb (2003) compared the performance of family firms' vis-à-vis non-family ones; they found out family businesses outperform non-family ones particularly when one of the family members is appointed as the CEO. However this result contradicts with other scholar findings who suggest family involvement is associated with lower productivity (Barth et al, 2005).Ali et al (2007) also using data related to S\&P 500 companies, suggests higher earnings quality in family firms than non-family firms, although family firms disclose less information compared to non-family ones. Miller(2007) indicates that superior performance of family firms is 
due to data bank and definition of family firm per se, to wit Microsoft is considered "lone founder" business with no family member in the managerial team whereas Comcast is run by the founder and its family. However separation of management and ownership vary across family businesses even in the same industry, for instance BMW or FIAT have hired professional manager after the founder retired whilst Peugeot is run by founder's heir.On the contrary Wong and Fan (2002) show that concentrated ownership is associated with low earnings quality partly because this ownership structure gives controlling owners the ability and incentive to manipulate earnings for outright expropriation or to report uninformative earnings to avoid detection of their expropriation activities" (p. 420). Meanwhile Jaggi (2009) indicates that monitoring effectiveness of corporate board is moderated in family-controlled firms by presence of family members on corporate board, which raises the possibility of earnings management in family firms. By aggregating four separate earnings management measures, Burgstahler et al (2006) showed that private companies of thirteen EU countries have more pervasive earnings management than public companies.However the Sarbanes-Oxley act (2002) emphasizes on several factors including independent corporate board in order to reduce earnings management. Findings of Dechow and Dichev (2002) show less earnings management in corporations with independent board. In this regard Xie et al (2003) found negative association between board independence and discretionary accruals.Although the full and transparent disclosure of accounting and financial information by family firms is not certain partly due to lack of conflict of interest in these organizations. Subsequentlyone can claimagency problems between managers and owners are mitigated thus the possibility of earnings management is higher compared to non-family organizations (Wang, 2006), which creates another type of agency problem between majority and minority shareholders (Cheung et al, 2006).Anderson et al (2009) demonstratedthat among the largest two thousand industrial firms in U.S. family firms are more opaque than non-family ones. In countries with low investor protection, higher earnings management in favor of majority shareholders is documented (Faccio et al, 2001). As Casson (1999) explains, family firms are mostly characterized by their long term perspective in which they do not assume the company as their wealth to consume by contrast they view the firm as their asset which is intended to be passed to succeeding generations. This in fact reduces the risk of investment by the managementwhich brings lower cost of equity capital as argued byZellweger (2007) and McNulty et al (2002).Abdolmohammdi and kvall (2010) documented that Norwegian family firms with high leverage ratio engage more in earnings management than non-family ones.Bertrand and Schoar (2006) demonstrated family firms make better investment decisions due to management's long-term focus in decision making. Albeit Stulz (1989) argued ownership concentration fosters poor quality management since takeover risk is mitigated, plus with high degree of family wealth in the company they usually tend to be risk averse and fail to implement profitable growth strategies (Fama and Jensen, 1983). Gallo et al (2004) also found out that family firm leverage and debt ratio were lower than non-family ones and sales/assets ratio was higher.However Villalonga and Amit's (2010) conclude that while all types of controlling families and individuals seek to maximize value for themselves, only founding families are willing and able to maximize value for all shareholders.

The accounting literature mentions several motivations behind earnings management, examples include debt covenants (Watts \& Zimmermann, 1986), bonus plans (McNichols\& Wilson, 1988), income smoothing (Buckmaster, 2001), dividend policy (Schmid, 2010) and insider trading (MacVay et al, 2006). An empirical study performed by Nelson et al (2003) show that in more than halve of the earnings management cases certain costs are manipulated by managers; impairment of assets, amortization and depreciation expense and risk provisions are examples. Sharma $(2001,2003,2004)$ attempts to distinguish family and non-family firms via stakeholder theory, while Zellweger et al (2008) use this theory to express different performance outcomes in family and non-family businesses. He argues that family firms have an additional stakeholder namely the family, which can have unique and non economic goals such as harmony and jobs for family members which is not defined in non-family organizations.

\section{Research Hypothesis}

The research hypothesis which seeks to compare earnings management in family and non-family businesses is as follow:

H1: There is a meaningful relationship between earnings management and firm's ownership structure in family and non-family context.

\section{Research Methodology}

This study follows cross correlation methodology which seeks to identify the relationship between ownership structure and earnings management of listed companies.31 family samples were identified according to the research criteria and were grouped in a separate portfolio with their related industry following TSE classification. 
According to proportion of each industry in the first portfolio, 31 non-family companies were selected randomly and put into second portfolio. The samples used in this survey are gathered from companies listed in TSE between 2002 and 2009.

\section{Models and Variable Presentation}

Independent variable in this research is ownership structure of firms which includes family and non-family enterprises. However the critical point in this realm is related to defining supportive and logical criteria for labeling a firm as a familyone. Having a strong influence on the board, being a member of the board or possessing a significant amount of firm's stock by the family members are examples. Shanker and Astrachan (1996) classify family business by degree of family involvement. Their three-tier categorization ranges from broad (little direct family involvement), to middle (some family involvement) and finally narrow (a lot of family involvement). Ehrhardt and Nowak (2000) have considered family businesses where $50 \%$ of firms stock belongs to a certain family whileAnderson and Reeb"Ibid"set the benchmark at 18\%. Villalonga and Amit (2006) have defined family businesses where a member of the family is the CEO or posses at least $5 \%$ of firm's stock or is a member of the board of directors. Deutsche Bourse Issuer Data \& Analytics (2010) has created a DAX plus index for defining family businesses where a family business has either one of the following characteristics:

1) Founder of the firm or its family posses at least $25 \%$ of the firm's stock;

2) One of the family members is a member of board of directors and at least owns $5 \%$ of the firm's stock.

Accounting standard No.20 in Iran explains where $20 \%$ or more of voting right belongs to certain person or family, significant influence on the firm is eidetic. Article 107 of commercial codes in Iran also requires companies to hold board of directors meetings with at least 5 individuals, thus had a person or family posses $20 \%$ of the firm's stock, it could be considered as a member of the board and through this they can execute their monitoring roles. In this research two criteria are set for identifying family firms:

1) Possessing at least $20 \%$ of firms stock by an individual,

Or

2) A member of the board posses at least $5 \%$ of firms stock.

Firms without these two characteristics are considered as non-family.

Dependent variable in this research is earnings management which has not a specific definition in accounting literature somehow because drawing a line between managing or manipulating earnings is rather unclear. Earnings management roots in manager's personal judgments in financial reporting whether they are trying to mislead the market or stakeholders due to firm's performance or perhaps signal the market through specific transactions or they might be related to certain covenants in contracts.Schipper (2003) defines earnings management as intentional interference in financial reporting in order to obtain personal benefits by management Measuring earnings management is not directly feasible; hence accounting literature proposes several estimation models for this phenomenon. However this study is based on the modified Jones model (Dechow\&Dichev, 2002) which uses discretionary accruals for earnings management. Accruals are usuallysegregated into discretionary and non discretionary where the first one is under management control, for instance executing particular accounting techniques and estimations plus having a discretion over recognizing certain items are common ways to manage earnings.

The information related to independentvariable such as ownership structure and the board's composition is extracted from board of director's report to annual shareholders meeting. Necessary information related to dependent variable such as earnings, sales, total assets, receivables, property, plant and equipment and cash flow are extracted from balance sheet, income and cash flow statement. These variables are depicted in table 1 . 
Table 1. Variables, data and reference data

\begin{tabular}{|c|c|c|c|}
\hline Variable & Criterion & Data & reference data \\
\hline \multirow{6}{*}{$\begin{array}{l}\text { Dependent: } \\
\text { earnings } \\
\text { management }\end{array}$} & \multirow{6}{*}{ discretionary accruals } & earnings & Income statement \\
\hline & & total assets & Balance sheet \\
\hline & & income & Income statement \\
\hline & & receivables & Balance sheet \\
\hline & & $\begin{array}{l}\text { property, plant and } \\
\text { equipment }\end{array}$ & Balance sheet \\
\hline & & cash flow & statement of cash flow \\
\hline Independent: & Possessing at least $20 \%$ of firms & Information about the & The board reports to the \\
\hline family & stock by an individual Or A & composition & General Assembly \\
\hline nonfamily & member of the board posses at & shareholders and board & Shareholders \\
\hline enterprises & least $5 \%$ of firms stock & members & \\
\hline
\end{tabular}

\section{Empirical Results}

After selecting appropriate firms for our family and non-family samples we segregated them into automotive manufacturing, metal products, fundamental metals, chemicals, food and beverage (sugar exempt), pharmaceuticals and others, totally seven groups based on TSE categorization. Sugar, mineral products, paper and textile products, plastic and electronic machinery were grouped as others for their relatively small sample. Afterwards themodified Jones model was executed to calculate discretionary accruals which represent the earnings management extent in family and non-family firms:

$$
T A_{i t}=N I_{i t}-O C F_{i t}
$$

Where

$\mathrm{TA}_{\mathrm{it}}$ : Total accruals of firm $\mathrm{i}$ in year $\mathrm{t}$,

$\mathrm{NI}_{\mathrm{it}}$ : net income before extraordinary items of firm $\mathrm{i}$ in year $\mathrm{t}$,

OCF: cash flow from operation of firm $i$ in year $t$,

After determining total accruals amount for each firm-year, the relationship between TA and sales, property, plant and equipment along with receivables were explored for each industry via following regression:

$$
\frac{T A_{i t}}{A_{i t-1}}=\alpha_{1}\left(\frac{1}{A_{i t-1}}\right)+\alpha_{2}\left(\frac{\Delta R E V_{i t}-\Delta R E C_{i t}}{A_{i t-1}}\right)+\alpha_{3}\left(\frac{P P E_{i t}}{A_{i t-1}}\right)+\varepsilon_{i t}
$$

Where

TA: total accruals,

A: total assets,

REV: sales,

REC: receivables,

PPE: property, plant and equipment. 
The result of regression model related to each industry is demonstrated below:

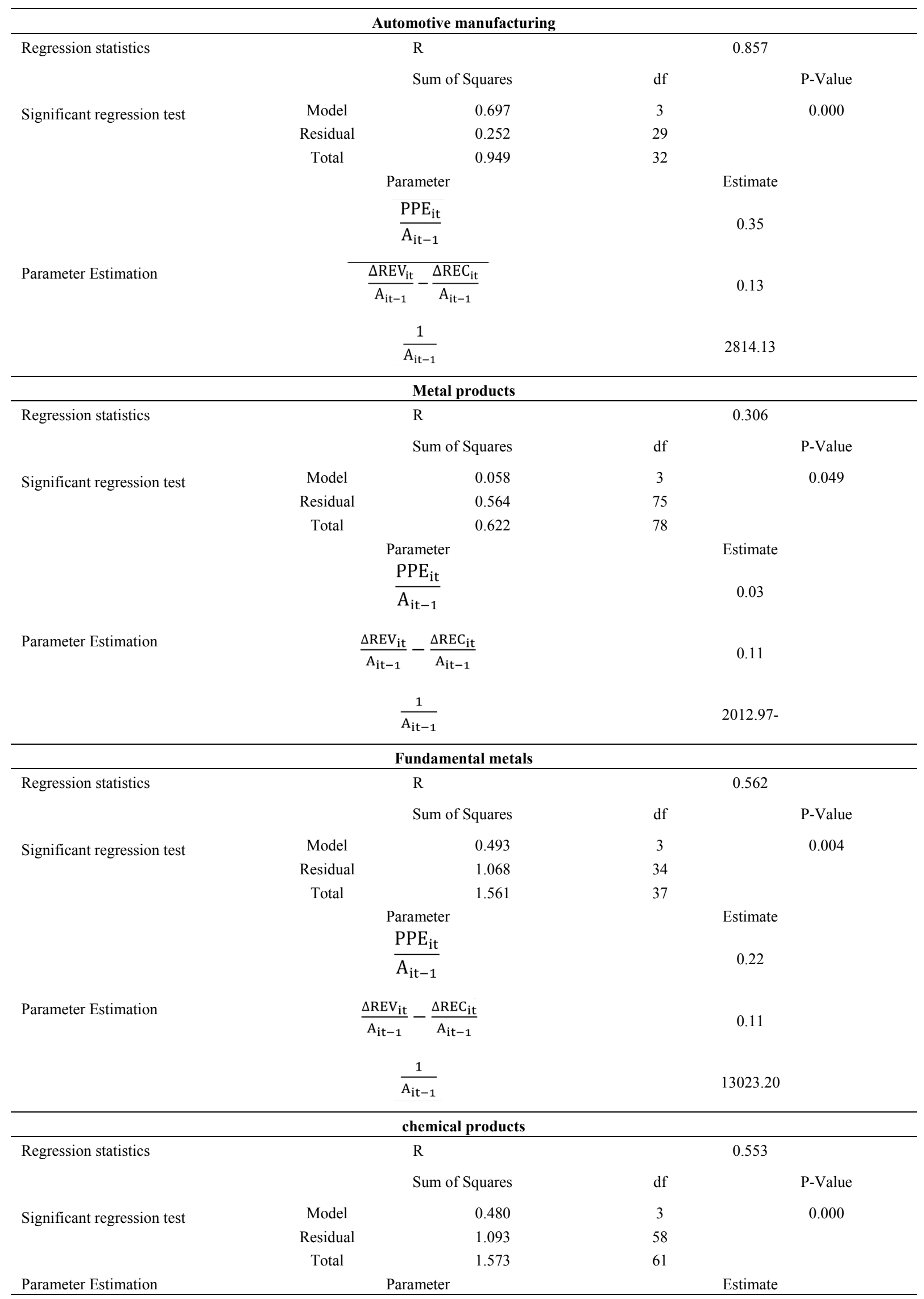




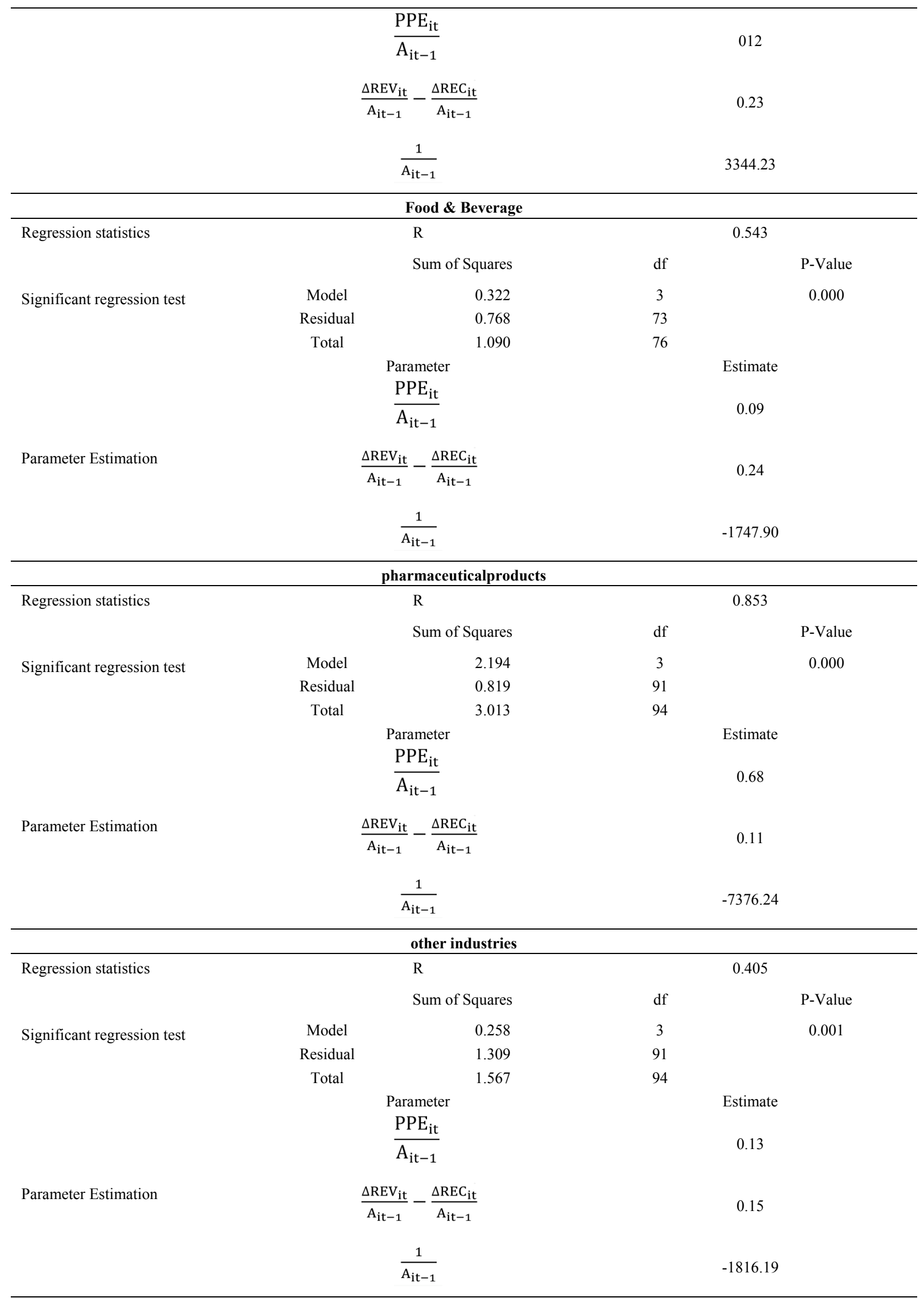


After estimating regression coefficients for each industry, NDA (non-discretionary accruals) and DA are computed for each group of samples (family and non-family businesses) respectively where the latest represents earnings management as it is shown below. Afterwards via comparing the means of two groups we explore the research hypothesis.

$$
N D A_{i t}=\alpha_{1}\left(\frac{1}{A_{i t-1}}\right)+\alpha_{2}\left(\frac{\Delta R E V_{i t}-\Delta R E C_{i t}}{A_{i t-1}}\right)+\alpha_{3}\left(\frac{P P E_{i t}}{A_{i t-1}}\right)
$$

DA amount is extracted via following formula:

$$
D A_{i t}=\frac{T A_{i t}}{A_{i t-1}}-N D A_{i t}
$$

The estimation error of regression model represents DA for each industry. The results are depicted in table 2.

\begin{tabular}{|c|c|}
\hline Industry & Equationtocalculate thediscretionary accruals \\
\hline automotive and parts manufacturing & $\mathrm{DA}_{\mathrm{it}}=\frac{\mathrm{TA} \mathrm{A}_{\mathrm{it}}}{\mathrm{A}_{\mathrm{it}-1}}-\left(2814 \frac{1}{\mathrm{~A}_{\mathrm{it}-1}}+0.13\left(\frac{\Delta \mathrm{REV} \mathrm{V}_{\mathrm{it}}}{\mathrm{A}_{\mathrm{it}-1}}-\frac{\Delta R E \mathrm{C}_{\mathrm{it}}}{\mathrm{A}_{\mathrm{it}-1}}\right)+0.35 \frac{\mathrm{PPE}_{\mathrm{it}}}{A_{\mathrm{it}-1}}\right)$ \\
\hline Manufacture of metal products & $\mathrm{DA}_{\mathrm{it}}=\frac{\mathrm{TA}_{\mathrm{it}}}{\mathrm{A}_{\mathrm{it}-1}}-\left(-2013 \frac{1}{A_{\mathrm{it}-1}}+0.11\left(\frac{\Delta \mathrm{REV} \mathrm{V}_{\mathrm{it}}}{A_{\mathrm{it}-1}}-\frac{\Delta \mathrm{RE} \mathrm{C}_{\mathrm{it}}}{A_{\mathrm{it}-1}}\right)+0.03 \frac{\mathrm{PPE}_{\mathrm{it}}}{A_{\mathrm{it}-1}}\right)$ \\
\hline Basic metals & $\mathrm{DA}_{\mathrm{it}}=\frac{\mathrm{TA}_{\mathrm{it}}}{\mathrm{A}_{\mathrm{it}-1}}-\left(13023 \frac{1}{\mathrm{~A}_{\mathrm{it}-1}}+0.11\left(\frac{\Delta \mathrm{RE} \mathrm{V}_{\mathrm{it}}}{A_{\mathrm{it}-1}}-\frac{\Delta \mathrm{RE} \mathrm{C}_{\mathrm{it}}}{\mathrm{A}_{\mathrm{it}-1}}\right)+0.22 \frac{\mathrm{PF}_{\mathrm{it}}}{A_{\mathrm{it}-1}}\right)$ \\
\hline Chemical products & $\mathrm{DA}_{\mathrm{it}}=\frac{T \mathrm{~A}_{\mathrm{it}}}{A_{\mathrm{it}-1}}-\left(3344 \frac{1}{\mathrm{~A}_{\mathrm{it}-1}}+0.23\left(\frac{\Delta \mathrm{REV}_{\mathrm{it}}}{A_{\mathrm{it}-1}}-\frac{\Delta \mathrm{RE}_{\mathrm{it}}}{A_{\mathrm{it}-1}}\right)+0.12 \frac{\mathrm{PPE}_{\mathrm{it}}}{A_{\mathrm{it}-1}}\right)$ \\
\hline Food \& Beverage & $\mathrm{DA}_{\mathrm{it}}=\frac{\mathrm{TA}_{\mathrm{it}}}{\mathrm{A}_{\mathrm{it}-1}}-\left(-1748 \frac{1}{\mathrm{~A}_{\mathrm{it}-1}}+0.24\left(\frac{\Delta \mathrm{REV} \mathrm{v}_{\mathrm{it}}}{\mathrm{A}_{\mathrm{it}-1}}-\frac{\Delta \mathrm{RE}_{\mathrm{it}}}{\mathrm{A}_{\mathrm{it}-1}}\right)+0.09 \frac{\mathrm{PPE}_{\mathrm{it}}}{\mathrm{A}_{\mathrm{it}-1}}\right)$ \\
\hline pharmaceutical products & $\mathrm{DA}_{\mathrm{it}}=\frac{\mathrm{TA}_{\mathrm{it}}}{\mathrm{A}_{\mathrm{it}-1}}-\left(-7376 \frac{1}{A_{\mathrm{it}-1}}+0.11\left(\frac{\Delta \mathrm{RE} \mathrm{V}_{\mathrm{it}}}{A_{\mathrm{it}-1}}-\frac{\Delta \mathrm{REC}_{\mathrm{it}}}{A_{\mathrm{it}-1}}\right)+0.68 \frac{\mathrm{PPE}_{\mathrm{it}}}{\mathrm{A}_{\mathrm{it}-1}}\right)$ \\
\hline Other Industries & $\mathrm{DA}_{\mathrm{it}}=\frac{T \mathrm{~A}_{\mathrm{it}}}{\mathrm{A}_{\mathrm{it}-1}}-\left(-1816 \frac{1}{A_{\mathrm{it}-1}}+0.15\left(\frac{\Delta R E V_{i t}}{A_{\mathrm{it}-1}}-\frac{\Delta R \mathrm{RE}_{\mathrm{it}}}{A_{\mathrm{it}-1}}\right)+0.13 \frac{\mathrm{PPE}_{\mathrm{it}}}{A_{\mathrm{it}-1}}\right)$ \\
\hline
\end{tabular}

Table 2.

According to findings, the mean of estimated DAs are close to zero while -0.507 and 0.393 represent min and max amounts which occurred in 2005 and 2009 respectively. Table 3 shows descriptive statistics of DAs for each year, afterwards they were tested for normality, the results indicate 1.007 kolmogorov-smirnovstatistic with p-value of 0.263 . Hencein order to assess the alternative hypothesis we compared the mean of earnings management samples in two groups using t-student, the results are shown in table 4.

Table 3. Descriptive statistics of discretionary accruals separately

\begin{tabular}{ccccc}
\hline Year & Minimum & Maximum & Average & Std. Deviation \\
\hline 2002 & -0.196 & 0.209 & 0.009 & 0.088 \\
2003 & -0.313 & 0.207 & -0.002 & 0.102 \\
2004 & -0.241 & 0.375 & 0.023 & 0.105 \\
2005 & -0.203 & 0.393 & 0.027 & 0.122 \\
2006 & -0.266 & 0.389 & 0.020 & 0.118 \\
2007 & -0.199 & 0.322 & 0.001 & 0.108 \\
2008 & -0.237 & 0.305 & 0.006 & 0.109 \\
2009 & -0.507 & 0.196 & -0.014 & 0.129 \\
\hline
\end{tabular}


Table 4. Results of hypothesis tests

\begin{tabular}{lllll}
\hline $\begin{array}{l}\text { Type of } \\
\text { company }\end{array}$ & $\begin{array}{l}\text { Average } \\
\text { discretionary } \\
\text { accruals }\end{array}$ & $\begin{array}{l}\text { Kolmogorov } \\
\text { Smirnov }\end{array}$ & P-Value & $\begin{array}{l}\text { Test } \\
\text { Results }\end{array}$ \\
\hline $\begin{array}{l}\text { family } \\
\text { Non-family }\end{array}$ & $\begin{array}{l}-0.002 \\
0.019\end{array}$ & 0.263 & 0.04 & Accept \\
\hline
\end{tabular}

It's evident that the mean of DAs in non-family firms is greater than family ones, with p-value of 0.04 and $95 \%$ confidence interval so the null hypothesis is rejected and the alternative is accepted. This means there is a meaningful relationship between earnings management and firm's ownership structure in family and non-family context.

\section{Conclusion}

Evaluating family firms' performance is useful for various decision makers such as shareholders, creditors and etc; however a consensus regarding the definition of family firms is not attained yet. Nevertheless the market share of family firms is soaring in TSE where in 2009 close to $11 \%$ of listed firms were classified as family business according to our criteria. By scrutinizing descriptive statistics, the most DAs which are considered as a proxy for earnings management occurred in 2005 where the political tension in Iran made the market fluctuate however Tehran Security Exchange Organization made this amount at its minimum in 2009 by passing transparent disclosure act. Non-family firms seem more appropriate for investors since they usually have strong and reliable ownership structure with professional managers running the organization however the Game theory suggests a less conflict of interest in family firms. This study attempts to compare the level of earnings management between family and non-family firms listed in TSE between 2002 and 2009. Hence 31 firms which satisfied the 2 criteria mentioned earlier were selected as family enterprises and subsequently 31 non-family firms were selected randomly. Then by using the t-student test a comparison between the mean of DAs which here are considered as a proxy for earnings management is executed. Findings show a meaningful relationship between ownership structure and earnings management, making the alternative hypothesis accepted.

\section{References}

Abdolmohammadi, M., \& Kvall, E. (2010). Earnings Management Priorities of Private Family Firms. American Accounting Association Annual Meeting, 31 July2010, San Francisco, CA.

Ali, Ashiq, Chen, Tai-Yuan, \& Radhakrishnan, Suresh. (2007). Corporate disclosure by family firms. Journal of Accounting and Economics, 44, 238-286.

Anderson, R., Duru, A., \& Reeb, D. (2009). Founders, heirs, and corporate opacity in the United States. Journal of Financial Economics, 92, 205-222. http://dx.doi.org/10.1016\%2Fj.jfineco.2008.04.006

Anderson, R.C., \& Reeb, D. (2003). Founding family ownership and firm performance: Evidence from S\&P500. Journal of Finance, 58, 1301-1328.

Andres, C. (2008). Large shareholders and firm performance - An empirical examination of founding family ownership. Journal of Corporate Finance (forthcoming).

Barth, E., Gulbrandsen, T., \& Schone, P. (2005). Family ownership and productivity: the role of

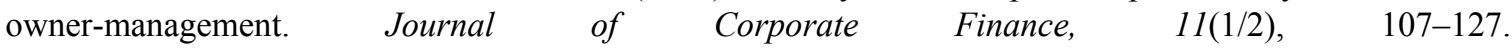
http://dx.doi.org/10.1016\%2Fj.jcorpfin.2004.02.001

Bertrand, Marianne., \& Antoinette Schoar. (2006). The Role of Family in Family Firms. Journal of Economic Perspectives, 20, 647-691. http://dx.doi.org/10.1257/jep.20.2.73

Buckmaster, D. (2001). Development of the income smoothing literature 1893-1998: A focus on the United States. Oxford, UK: Elsevier Science Ltd.

Cheung, Y.L., Rau, P.R., \& Stouraitis, A. (2006). Tunneling, propping, and expropriation: Evidence from connected party transactions in Hong Kong. Journal of Financial Economics, 82, 341-386. http://dx.doi.org/10.1016/j.jfineco.2004.08.012

Dechow, P., \& Dichev, D. (2002). The Quality of Accruals and Earnings; the Role of Accrual Estimation Errors. The Accounting Review, 77, 35-59. http://dx.doi.org/10.2308/accr.2002.77.s-1.35 
Dechow, P., Sloan, R., \& Sweeney, A. (1996). Cause and consequences of Earnings Manipulation: An Analysis of firms subject to enforcement actions by the SEC. Contemporary Accounting Research, 13, 1-36. http://dx.doi.org/10.2307/2491422

Faccio, M., Lang, L., \& Young, L. (2001). Dividends and expropriation. American Economic Review, 91(1), 54-78. http://dx.doi.org/10.1257/aer.91.1.54

Fama, Eugen, \& Michael Jensen. (1983). Separation of ownership and control. Journal of Law and Economics, 26, 301-325. http://dx.doi.org/10.1086/467037

Fan, J., \& Wong, T.J. (2002).Corporate ownership structure and the informativeness of accounting earnings in East Asia. Journal of Accounting and Economics, 33, 401-425. http://dx.doi.org/10.1016/S0165-4101(02)00047-2

Gallo, M.A., Tapies, J., \& Cappuyns, K. (2004). Comparison of family and nonfamily business: Financial logic and personal preferences. Family Business Review, 17(4), 303-318.

Hendriksen, E., \& Van Brada, M. (1991). Accounting Theory (5th Edition). New York: IRWIN.

Jaggi, B., Leung, S., \& Gul, F. (2009). Family control, board independence and earnings management: Evidence based on Hong Kong firms. Journal of Accounting and Public Policy, 28(4), 281-300. http://dx.doi.org/10.1016/j.jaccpubpol.2009.06.002

McNichols, M., \& Wilson, G. P. (1988). Evidence of earnings management from the provision for bad debts. Journal of Accounting Research, 26, 1-40. http://dx.doi.org/10.2307/2491176

McNulty, J. J., Yeh, T. D., Schulze,W. S., \& Lubatkin, M. S. (2002). What's your real cost of capital? Harvard Business Review, 80(10), 114-121.

McVay, S., Nagar, V., \& Tang, V. W. (2006). Trading incentives to meet earnings thresholds. Review of Accounting Studies, 11(4), 575-598. http://dx.doi.org/10.1007/s11142-006-9017-9

Miller, D., Miller, I. L. B., \& Lester, R. (2007). Are family firms really superior performers? Journal of corporate finance, 13(5), 829-858. http://dx.doi.org/10.1016/j.jcorpfin.2007.03.004

Mishra, C., Randqy, T., \& Jenssen, J. (2001). The Effect of Founding Family Influence on Firm Value and Corporate Governance. Journal of International Financial Management and Accounting, 12, 235-259. http://dx.doi.org/10.1016/j.jcorpfin.2007.03.004

Nelson,M.W., Elliott, J. A., \& Tarpley, R. L. (2003). How are earnings managed? Examples from auditors. Accounting Horizons, Supplement, 17-35.

Schipper, K., \& Vincent, L. (2003). Earning Quality. Accounting Horizons, 17, 97-110. http://dx.doi.org/10.2308/acch.2003.17.s-1.97

Schmid, T., Ampenberger, M., Kaserer, C., \& Achleitner, A.-K. (2010). Controlling Shareholders and Payout Policy: Do Founding Families Have a Special 'Taste for Dividends'?, Working Paper.

Shanker, M. C., \& Astrachan, J. H. (1996). Myths and realities: Family businesses' contribution to the US economy-A framework for assessing family business statistics. Family Business Review, 9(2), 107-119.

Sharma, P. (2001). Stakeholdermanagement concepts in family firms. Proceedings of International Association of Business and Society (IABS), 254-259.

Sharma, P. (2004). An overview of the field of family business studies: Current status and directions for the future. Family Business Review, 17(1), 1-36. http://dx.doi.org/10.1111/j.1741-6248.2004.00001.x

Sharma.P. (2003). A typology of family firms using internal stakeholders. Proceedings of the Administrative Sciences Association of Canada's Annual Conference in Halifax. Entrepreneurship Division, 24, 149-163.

Stulz, René. (1988). Managerial control of voting rights: Financing policies and the market for corporate control. Journal of Financial Economics, 20, 25-54. http://dx.doi.org/10.1016/0304-405X(88)90039-6

Villalonga, B., \& Amit, R. (2006). How do family ownership, control and management affect firm value? Journal of Financial Economics, 80, 385-417.

Villalonga, B., \& Amit, R. (2010). Family Control of Firms and Industries. Financial Management, 39(3), 863-904. http://dx.doi.org/10.1111/j.1755-053X.2010.01098.x

Wang, D. (2006). Founding Family Ownership and Earning Quality. Journal of Accounting Research, 44, 619-656. http://dx.doi.org/10.1111/j.1475-679X.2006.00213.x 
Watts, R., \& Zimmerman, J. (1986). Positive Accounting Theory. Prentice-Hall, Englewood Cliffs, NJ.

Xie, B., Davidson III, W.N., \& DaDalt, P.J. (2003). Earnings management and corporate governance: The roles of the board and the audit committee. Journal of Corporate Finance, 9, 295-316. http://dx.doi.org/10.1016/S0929-1199(02)00006-8

Zellweger, T. (2007). Time horizon, costs of equity capital, and generic investment strategies of firms. Family Business Review, 20(1), 1-15. http://dx.doi.org/10.1111/j.1741-6248.2007.00080.x

Zellweger, T., \& Nason, R. (2008). A Stakeholder Perspective on Family Firm Performance. Family Business Review, XXI(3), September 2008. http://dx.doi.org/10.1177/08944865080210030103 